УДК 323.2(477):316.61

\title{
О.В. Мендрін
}

\section{ФОРМУВАННЯ МАКРОПОЛІТИЧНОЇ ІДЕНТИЧНОСТІ ЯК ФАКТОР СТАЛОСТІ ДЕМОКРАТИЧНОГО РОЗВИТКУ В УКРАЇНІ}

У статті проаналізовані процеси, щзо обумовлюють кризове становище політичної модернізації, демократичного розвитку Украӥни. Досліджується взаємовплив процесів демократизачії та формування макрополітичної ідентичності на основі консолідації українського суспільства довкола демократичних ичінностей. Визначається, щзо суттєвим фактором стабільності демократії та політичного розвитку, формування консолідованої макрополітичної ідентичності та укорінення демократичних цінностей виступає розвиток інститутів громадянського суспільства, врахування емансипаційних иінностей украйнських громадян при формуванні курсу політичного розвитку держави, при прийнятті політичних рішень.

Ключові слова: макрополітична ідентичність, сталість демократичного розвитку, громадянське суспільство, транзит.

DOI 10.34079/2226-2830-2020-10-28-29-242-251

Незмінність прагнення та важливість процесу демократичного транзиту України, визначення демократії у якості принципу вибудови держави та суспільства, були зазначені у переважній більшості базових для суспільно-політичного розвитку країни документів: від Декларації про державний суверенітет та Конституції України до програм і стратегій, декларованих на урядовому та президентському рівнях. Однак, попри таке широке визнання та високе представлення, демократичний транзит лишається незавершеним процесом, таким, що подеколи обумовлює актуалізацію проблеми незворотності процесів суспільнополітичних перетворень, які б засвідчили проходження країною етапу консолідації. Відповідно до «Індексу демократії», що його вираховує The Economist Intelligence Unit, Україна з 2011 року належить до так званих «гібридних режимів» (The Economist Intelligence Unit's Democracy Index, 2020). 3 того ж часу, не відмічає суттєвого прогресу в процесі демократичного транзиту України Freedom House (Yesmukhanova, 2018), водночас, останній оприлюднений звіт Polity IV (2017 року) характеризує політичний режим в Україні як «відкриту анократію» (Marshall and Elzinga-Marshall, 2017). Наявні для спостереження тенденції суспільно-політичного розвитку України дозволяють говорити про амбівалентність поступу в процесі демократизації та буксування політичної модернізації. Зокрема, відомий український дослідник М. Мінаков говорить про загальну «демодернізацію» України, вирізняючи в цьому контексті такі явища, як «деіндустріалізація, десоціалізація та деінституціалізація» які на його думку, притаманні сучасному розвитку України, зазначаючи, що їх, на поточному етапі, значно посилює «російське вторгнення в Крим та конфлікт у Україні» (Minakov, 2018, с.258). Разом із тим, задекларований демократичний вибір країни, як стратегія політичного розвитку та необхідний прогрес на цьому шляху, виявляється пов'язаним із такими важливими характеристиками сучасного розвитку держави та суспільства як криза макрополітичної 
ідентичності та незадовільний стан розвитку інститутів громадянського суспільства. Необхідність розуміння складності, взаємного поєднання вищезазначених процесів та окреслення можливих способів подолання кризових тенденцій в їхньому розвитку обумовлюють актуальність дослідження.

Наша мета, в даній статті, полягає в дослідженні взаємного впливу процесів формування макрополітичної ідентичності та розвитку демократії в Україні, визначення того, як становлення інститутів громадянського суспільства позначається на цих процесах.

Питання сутності та характеристик відповідних етапів, можливого впливу факторів різного типу на процес демократичних змін отримали значну увагу з боку великої кількості науковців, серед яких, 3 огляду на поставлену мету, варто відмітити Л. Даймонда, А. Лейпхарта, Х. Лінца, Д. Растоу, А. Степана та С. Хантінгтона. Зв’язок демократичних перетворень та розвитку інститутів громадянського суспільства, концептуалізації та втілення політики ідентичності, впливу культурних факторів розкривається в роботах зарубіжних: Г. Алмонда, С. Верби, Е. Внук-Липинського, Г. Екстайна, Р. Інглхарта, П. Норіс, Р. Патнема, Й. Шапіро, Ф. Шміттера та вітчизняних: Т. Бевз, О. Зорич, М. Кармазіної, Н. Пашиної, М. Розумного дослідників. Втім, особливості українського демократичного транзиту, що вирізняють його 3-поміж інших пострадянських країн, те як вони визначають особливості формування соціального капіталу, реалізації стратегій формування макрополітичної ідентичності потребують подальшого дослідження.

Сучасне розуміння процесів, що забезпечують повноту та незворотність демократичного транзиту передбачає консенсус щодо необхідності виокремлення, в більшій сукупності випадків, декількох рівнів (визначених як такі, що посилюють якість) демократичності політичного режиму. Певну рамку для представлення спектру варіативності можливих моделей демократії тут формують поняття про ліберальну (в розумінні, обгрунтованому Л. Даймондом) та електоральну чи то мінімальну демократії (Даймонд, 1999, с.11-15). Запропоновані Р. Далем поняття поліархії та підхід до операціоналізації концепту демократії, мали за мету вихід за межі термінологічних обмежень, а саме означення необхідних якісних характеристик на шляху наближення до демократичного ідеалу (Даль, 2010, с.14-15). Вони були ширко використані політичною наукою для пояснення трансформаційних процесів у країнах, що проходили шляхом демократизації, перетворюючись з гегемоній та конкурентних олігархій на «майже» а, згодом, повноцінні поліархії (Даль, 2010, с.16-18).

Однак, специфіка всієї складної сукупності суспільних, культурних, економічних, внутрішньополітичних перетворень, що відбувались у пострадянських країнах після розпаду Радянського Союзу, яка визначила особливості так званої «третьої хвилі» демократизації, змусила шукати нову термінологію, давати пояснення й коригувати наявні моделі що були запропоновані у якості певних рецептів, дороговказів для транзитних переходів. Результати «третьої хвилі», водночас, дозволили ставити під сумнів, власне, теорію демократичного транзиту загалом. Намагаючись знайти пояснення для «згасання» хвилі, все більше уваги дослідники почали приділяти поняттю «гібридного режиму», розуміючи під ним політичний режим, що поєднує риси авторитаризму і демократії. У запропонованих типологізаціях посталих гібридних режимів, вироблялись моделі, які майже ніколи не враховували увесь спектр особливостей. Натомість, вони будувались на характерних рисах окремих країн, переважно таких, що сприймались як найбільш впливові в регіоні чи-то такі, в яких ті або інші тенденції знайшли найбільш виразний прояв. Такого типу моделі, у разі їхнього узагальнення та подальшого екстраполювання на інші країни 
пострадянського простору, мали своїм наслідком нівелювання наявних між цими країнами важливих для політичного аналізу відмінностей. Зазначена нерозбірливість у застосуванні поняття, призводила до того, що окремі риси «гібридних режимів», які ставали головною ознакою при їхньому вирізненні, могли не співпадати з виділеними на інших прикладах ознаками гібридності. Відповідно, застосування характеристики «гібридного режиму» завжди вимагає пояснення та уточнення характеристик, які обумовлюють цю якість. Зокрема, український дослідник Ю. В. Мацієвський звертає увагу на те, що особливість гібридного стану українського режиму полягає «не в коливанні між демократією та авторитаризмом, як це зазвичай представлено у літературі», а в тому, що «вплив неформальних інститутів на формальні зростає, що призводить до їхнього «псування», зокрема до інволюції конституціоналізму [...] та послабленню адміністративного потенціалу держави [...], переважанню неформальної політики в політичному процесі» (Мациевский, 2018, с.98). Можна погодитись із автором відносно того, що, «неефективна інституційна рівновага (інституційна пастка), що склалась в Україні ще 3 середини 1990-х років, демонструє здатність до збереження та відтворення навіть в умовах війни та незакінченої революції» (Мациевский, 2018, с.110).

Разом із тим, більшої уваги потребує вивчення впливу на процес виходу із стану гібридності таких факторів, як політична культура, суспільні цінності, розвиток соціального та культурного капіталу тощо. Навряд чи зазначені фактори можна вважати такими, що визначають лише стилістичні особливості політичного процесу, і не впливають на його сутнісне наповнення.

У переліку таких, що справляють найбільш значний вплив на процес модернізації політичної системи, визначаючи просування України на шляху побудови демократії, можна відзначити: 1) несталість основних, як для сучасних демократій, інститутів; 2) високий рівень корупції, що уповільнює розвиток демократичних інститутів (не випадково, боротьба із цим явищем лишається однією з вимог українського суспільства, що на думку експертів може найбільше його згуртувати (Центр Разумкова, 2017c, с.84); 3) слабкість держави («weak state»), - за показниками «Рейтингу крихких держав» (Fragile States Index), Україна з 2014 року характеризується як загрозливо нестійка держава («Warning», 3 відповідним індексом, вищим за 70) (Fragile States Index, 2014). Зазначені тенденції значно погіршують зовнішня військова агресія та окупація частини території країни. Треба відмітити, що базові ознаки «слабких держав» постійно виявляють себе в якості елементів, притаманних українській політичній системі, серед них: 1) недостатній для забезпечення мінімального рівня добробуту населення розвиток економіки; 2) слабкий розвиток форм соціального капіталу, що не може гарантувати створення макрополітичної спільноти (політичної нації); 3) брак ефективних та відповідальних інститутів; 4) некомпетентний і корумпований бюрократичний апарат з політичними лідерами, які не дбають про забезпечення суспільного блага (Sørensen, 2010, с.448-450).

Певний інструментарій для об'єднання та скеровування в одне русло суспільних інтересів, створення джерел для оформлення балансу влади, і загалом, послаблення зазначених кризових явищ, можуть створювати інститути громадянського суспільства (Шмиттер, 1996, с.24). В Україні, незважаючи на деякий поступ у цьому напрямі, інститути громадянського суспільства майже не включені у процеси вироблення, відбору та прийняття рішень. Таке твердження підкріплюється й тим, що затверджена у 2016 році «Національна стратегія сприяння розвитку громадянського суспільства в Україні на 2016-2020 роки», на думку експертів, виконується незадовільно, план іiі заходів був 
ISSN 2518-1521 (Online), ISSN 2226-2830 (Print) ВІСНИК МАРІУПОЛЬСЬКОГО ДЕРЖАВНОГО УНІВЕРСИТЕТУ СЕРІЯ: ІСТОРІЯ. ПОЛІТОЛОГІЯ, 2020, ВИП. 28-29

виконаний лише на 45\% у 2018 році (Корнієвський, Тищенко та Яблонський, 2018, с.5-7). Незважаючи на продовження реалізації цієї стратегії (фінальний звіт з виконання якої має бути підготовлений до кінця 2020 року, за наказом Уряду України) навряд чи можна очікувати іiі повного виконання. До таких висновків спонукає, зокрема, моніторингове дослідження з ії імплементації. За оновленою оцінкою, не виконаними на 2019 рік лишались $58 \%$ із запланованих завдань, тобто перегляд виконаних завдань засвідчив навіть певне погіршення ситуації з реалізацією стратегії (Заславський, Скрипець та Соколова, 2019, с.16).

Ускладнює умови розвитку громадянського суспільства вкрай низький рівень довіри людей один до одного, атомізація і відсутність досвіду нормальної громадянської інтеграції та взаємодії. Таке становище, притаманне більшості пострадянських країн. Воно значно впливає як на можливості організації громадянського протесту, так і на здатність до самоорганізації задля вирішення суспільно важливих питань, а отже, сприяє укоріненню впевненості щодо неспроможності домогтись задовільного рівня соціальної відповідальності влади. Українці, в переважній більшості, лишаються апатичними до різних форм соціальної взаємодії, що не була поширена у Радянському Союзі. Відповідно до результатів опитувань, проведених Фондом «Демократичні ініціативи» у жовтні 2019 року, $51 \%$ опитаних не планує брати участь у роботі громадських організацій, а профспілки лишаються лідерами серед типів громадських об'єднань, що до них залучені громадяни. Загальний спад активності спостерігається й у волонтерському русі, на розвиток якого покладали певні сподівання, як на дієвий та креативний механізм, здатний принципово змінити ситуацію в цьому напрямі. Втім, згідно із даними соціологічного опитування, кількість залучених у таку діяльність скоротилась з 18\% вдвічі проти минулого року. Варто зауважити й на тому, що значним лишається відсоток тих, хто свою неучасть у діяльності громадських організацій пояснює необізнаністю щодо такої сфери $(21,2 \%)$ та зневірою у

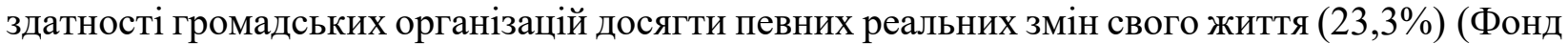
Демократичні Ініціативи ім. Ілька Кучеріва, 2019).

Зазначена сукупність чинників посилює існуючу кризу легітимності політичної влади, що, у свою чергу, корелює з кризою пострадянської (для України зберігають актуальність відмінні елементи як постколоніального так і посттоталітарного дискурсу) та несталістю української макрополітичної ідентичності.

Водночас, зберігають дискусійний потенціал питання про природу чинників, які мають стати базовими для вирізнення та згуртування макрополітичної спільноти, що формують спектр можливих комбінацій між полюсами культурно-національних та громадянських і політичних рис та цінностей. Можна відмітити невизначеність як на експертному рівні, так і з боку владних інститутів, які мали б стати головними акторами у виробленні та імплементації стратегії формування макрополітичної ідентичності, щодо основних принципів та компонентів, навколо яких повинно відбуватись формування такої стратегії. Починаючи з 2007 року аналітичними (Центр Разумкова, 2007; Центр Разумкова, 2017b) та науковими центрами (Розумний, ред., 2011), окремими дослідниками (Пашина, 2013) були запропоновані концепції формування політики ідентичності, які ніколи не були імплементовані та не були покладені в основу державних програм, незважаючи на проведену, зокрема, Центром Разумкова, кількарічну роботу з вивчення широкого обсягу емпіричних даних, що характеризують різні аспекти соціально-політичного розвитку українського суспільства, залучення до обговорення програми широкого кола експертів тощо. Разом із тим, запропоновані концепції потребують доопрацювання і вдосконалення, головно в напрямках деталізації аспектів практичного запровадження, узгодження i 
знаходження балансу та відповідності запропонованих засадничих положень і принципів, 3 одного боку, та суспільних цінностей і прагнень, з іншого.

Отже, наявний стан вироблення політики макрополітичної ідентичності також можна вважати проявом іiі кризи. Яка, своєю чергою, спричинена, як відсутністю у суспільстві консенсусу щодо базових суспільно-політичних цінностей, так i очевидною незацікавленістю владних еліт у зміні сформованого status quo щодо механізмів прийняття політичних рішень, дисбалансу владних повноважень та виправлення проблем суспільнополітичного розвитку. Така ситуація є загрозливою для політичної системи в цілому, адже задля збереження стабільності, вона має підтримувати певний рівень легітимності, здатності забезпечувати виконання суспільних потреб у спосіб, що відповідає очікуванням та домінуючим суспільним представленням.

Разом із тим, слід враховувати, що інститути громадянського суспільства можуть чинити як позитивний, так i негативний вплив на процес демократизації (Шмиттер, 1996, с.24-25), що висуває відповідні вимоги до держави, обумовлені необхідністю забезпечити базові функції дотримання норм права та суспільного порядку. На таку нагальну необхідність вказували як політологи, так і економісти, зокрема, С. Хантінгтон у роботі «Політичний порядок у мінливих суспільствах» та Д. Аджемоглу у «Чому нації занепадають?».

Існування залежності виникнення та подальшого стабільного розвитку демократичних режимів від масових переконань громадян, лишається дискусійною темою, попри те, що серед прихильників цієї думки можна відзначити багатьох авторитетних політологів, зокрема, Г. Алмонда, С. Вербу, Р. Інглхарта, Г. Лассвела, С. М. Ліпсета, С. Хантінгтона. Досліджуючи вплив культурних чинників, цінностей та переконань на процеси політичного розвитку, Г. Алмонд та С. Верба (1963), а згодом Г. Екстайн (1966) запропонували тезу про «конгруентність» (узгодженість, сумісність), а Р. Інглхарт та К. Вельцель «узагальнили гіпотезу, припустивши, що політичні режими здатні вижити, тільки за умови, що рівень їхньої демократичності $є$ достатнім для задоволення запиту на демократію 3 боку населення» (Вельцель и Инглхарт, 2015, с.234-235).

У викладі Г. Екстайна, теорія конгруентності базується на двох припущеннях, які передбачають, що, по-перше, «урядові інститути (governments) функціонують добре, в тій мірі, в якій їх владні патерни конгруентні владним патернам інших одиниць в суспільстві», а по-друге: «демократичні уряди працюють добре лише в тому випадку, якщо їх моделі влади демонструють «збалансовану нерівність», тобто поєднання демократичних i недемократичних рис» (Eckstein, 1997). Постулюючи необхідність співвідносити рівень демократичності державних інститутів 3 домінуючими в суспільстві уявленнями про демократію, дана теорія дозволяє позначити ступінь узгодження суспільних цінностей 3 тими, які суспільство буде хотіти бачити і в прийнятих державних рішеннях.

Як засвідчують результати опитувань, проведених Центром Разумкова, збереження демократичного ладу в країні $є$ доволі важливим для українців, причому цей показник, не значно коливаючись, збільшується для громадян молодше 50-річного віку (Центр Разумкова, 2017a, с.45,49). Значення демократії, поваги до прав людини, небажання толерувати корумпованість та неефективність владних структур, необхідність модернізації політичних інститутів України продемонтрували події «Революції Гідності», визначивши межу припустимості ігнорування політичними елітами суспільних настроїв.

Водночас, уявлення українців про сутність демократії зберігають певну розмитість: в переліку якостей демократії, представлених у результатах соціологічного дослідження, 
наявні характеристики, що, відповідно до вже зазначених політологічних моделей, не $\epsilon$ iї критеріями (наприклад, державна підтримка соціально уразливих верств населення, регулювання податкового навантаження) (Центр Разумкова, 2017а, с.47). Їхня присутність у визначеннях ознак демократії демонструє наявність зв'язку в масових суспільних представленнях між ідеями про демократію та соціальну державу. Зазначена кореляція не тільки виступає певною ознакою стану політичної культури, але й може стати фактором ризику для збереження схильності громадян до підтримки демократичних цінностей, наприклад, при розчаруванні у соціальній політиці держави. Однак, саме емансипаційні цінності (такі, що пов'язані із представленнями про свободу, рівність, незалежність у прийнятті рішень), в випадку коли велика частина суспільства усвідомлює їх зв’язок із розвитком демократії, стають основним джерелом іiі підтримки i захисту, адже «переконання, що лежать за уподобаннями людей на користь демократії, так само важливі, як і сам факт таких переконань» (Вельцель и Инглхарт, 2015, с.237).

Враховуючи вищевикладене, можна зробити певні висновки. Кризовий стан, що виступає постійною характеристикою суспільно-політичного розвитку України, обумовлений комплексом причин, серед яких окремо можна виділити проблеми реформування інститутів, труднощі становлення громадянського суспільства, відсутність стійкого консенсусу щодо ціннісних установок, які повинні визначати вектор трансформаційних процесів. При цьому, поширені у суспільстві уявлення про суть політичних процесів, феноменів, що відносяться до сфери політичної культури, істотно впливають на динаміку політичної модернізації. Демократія, як політичний вибір більшості громадян України, узгоджується з емпіричними даними щодо визнання її українцями як цінності, і знаходить підтвердження в конкретних подіях політичного розвитку країни. Висновки, які випливають з теорії конгруентності вказують на те, що ідеали та цінності, які не вкорінені в суспільстві, будучи трансльовані владою, не зможуть сформувати основу для iii легітимності. Водночас, країни, де в основу макрополітичної ідентичності покладено політичні, громадянські принципи, - показують більшу стабільність і успішність.

Отже, поточний стан суспільно-політичного розвитку вимагає цілеспрямованих зусиль держави і політичних еліт, спрямованих не тільки на певну «корекцію» успадкованих уявлень про сутність політичних явищ, а й на стимулювання явних, стійких, i, в той же час, важливих для розвитку держави і суспільства політичних переконань, емансипаційних ціннісних установок, які пануватимуть у масовій свідомості, сприяючи прогресу політичної модернізації і подоланню «відкотів» у демократизації. Серед напрямів реалізації таких зусиль може бути представлене вироблення та запровадження політики макрополітичної ідентичності, однією з вагомих особливостей якої має стати сприяння усвідомленню демократії як сутнісної риси макрополітичної спільноти та важливої мети розвитку. Така політика підтримуватиме розвиток демократії та виступатиме як стримуючий фактор для демодернізаційних тенденцій. Вона має сприяти певному посиленню держави та подоланню причин, які обумовлюють стан «слабкої держави». Водночас, зазначена політика, за свого впровадження, не має нехтувати підтримкою інклюзивного, плюралістичного за принципом побудови, публічного простору, в рамках якого може відбуватись іiі коригування, пошук прийнятних для суспільства форм реалізації.

\section{Бібліографічний список}

Вельцель, К. и Инглхарт, Р.Ф., 2015. Политическая культура, массовые убеждения и изменение ценностей. Перевод с англ. И.М. Локшина. В: К.В. Харпфер, П.Бернхаген, 
ISSN 2518-1521 (Online), ISSN 2226-2830 (Print)

ВІСНИК МАРІУПОЛЬСЬКОГО ДЕРЖАВНОГО УНІВЕРСИТЕТУ

СЕРІЯ: ІСТОРІЯ. ПОЛІТОЛОГІЯ, 2020, ВИП. 28-29

Р.Ф. Инглхарт и К. Вельцель, ред., 2015. Демократизаџия. Москва: ГУ ВШЭ, с.233261.

Даймонд, Л., 1999. Прошла ли «третья волна» демократизации? Полис. Политические исследования, 1, с.10-25.

Даль, Р.А., 2010. Полиархия: участие и оппозиция. Москва: ГУ ВШЭ.

Заславський, О., Скрипець, В. та Соколова, М., 2019. Моніторингове дослідження Національна стратегія сприяння розвитку громадянського суспільства в Україні. 2016-2020. Лабораторія законодавчих ініміатив. [онлайн] Доступно: <https://parlament.org.ua/wp-content/uploads/2019/12/Brochure_10.12.19_final.pdf> (Дата звернення 15 вересня 2020).

Корнієвський, О.А., Тищенко, Ю.А. та Яблонський, В.М., 2018. Громадянське суспільство Украӥни: сучасні практики та виклики розвитку. Аналітична доповідь. Київ: НІСД.

Мациевский, Ю.В., 2018. В ловушке гибридности: политический режим в Украине после революции 2014 года. Полис. Политические исследования, 1, с.96-115. DOI: 10.17976/jpps/2018.01.07

Пашина, Н.П., 2013. Формування політичної ідентичності в умовах демократичної трансформації українського суспільства. Луганськ: Ноулідж.

Розумний, М.М., ред., 2011. Украӥна: політичні стратегї модернізації. Київ: НІСД.

Фонд Демократичні Ініціативи ім. Ілька Кучеріва, 2019. Громадянське суспільство в Україні: погляд громадян. Опитування. [онлайн] Доступно: $<$ https://dif.org.ua/article/gromadyanske-suspilstvo-v-ukraini-poglyad-gromadyan> (Дата звернення 15 вересня 2020).

Центр Разумкова, 2007. Концепція формування загальнонаціональної ідентичності громадян України. Національна безпека і оборона, 9, с.28-31.

Центр Разумкова, 2017а. Ідентичність громадян України: ціннісно-орієнтаційний аспект. Національна безпека і оборона, 1-2, с.3-61.

Центр Разумкова, 2017b. Концепція формування загальнонаціональної ідентичності громадян України (Проект). Національна безпека і оборона, 1-2, с.89-94.

Центр Разумкова, 2017с. Процес формування спільної загальнонаціональної ідентичності громадян: чинники впливу, основні засади і напрями (Експертне опитування). Національна безпека і оборона, 1-2, с.77-88.

Шмиттер, Ф., 1996. Размышления о гражданском обществе и консолидации демократии. Полис. Политические исследования, 5, с.16-27.

Eckstein, H., 1997. Congruence Theory Explained. Center for the Study of Democracy. [online] Available at: <https://escholarship.org/uc/item/2wb616g6> (Accessed 15 November 2020).

Fragile States Index, 2014. Tableau Public. [online] Available at: <https://public.tableau.com/profile/davidnicole\#!/vizhome/FragileStatesIndex2014/Fragil eStates> (Accessed 15 September 2020).

Marshall, M.G. and Elzinga-Marshall, G.C., 2017. Global Report 2017: Conflict, Governance and State Fragility. Center for Systemic Peace. [online] Available at: <http://www.systemicpeace.org/vlibrary/GlobalReport2017.pdf> (Accessed 15 September 2020).

Minakov, M., 2018. Demodernization in Post-Soviet Eastern Europe. In: Y. Rabkin and M. Minakov, eds., 2018. Demodernization: A Future in the Past. Stuttgart: ibidem-Verlag, pp. 241-260. 
ISSN 2518-1521 (Online), ISSN 2226-2830 (Print) ВІСНИК МАРІУПОЛЬСЬКОГО ДЕРЖАВНОГО УНІВЕРСИТЕТУ СЕРІЯ: ІСТОРІЯ. ПОЛІТОЛОГІЯ, 2020, ВИП. 28-29

Sørensen, G., 2010. Democracy and Democratization. In: K.T. Leicht, J.C. Jenkins, eds., 2010. Handbook of Politics: State and Society in Global Perspective. New York: Springer, pp.441-458.

The Economist Intelligence Unit's Democracy Index, 2020. The Economist, [online] 22 January. Available at: <https://www.economist.com/graphic-detail/2020/01/22/global-democracyhas-another-bad-year> (Accessed 15 September 2020).

Yesmukhanova, Y., 2018. Nations in Transit 2018. Ukraine. Freedom House. Available at: <https://freedomhouse.org/country/ukraine/nations-transit/2018> (Accessed 15 September 2020).

\section{References}

Dahl, R.A., 2010. Poliarkhiya: uchastie i oppozitsiya [Polyarchy: Participation and Opposition]. Moscow: GU VShE. (In Russian).

Diamond, L., 1999. Proshla li tretya volna demokratizatsii [Is the Third Wave Over?]. Polis. Political Studies, 1, pp.10-25. (In Russian).

Eckstein, H., 1997. Congruence Theory Explained. Center for the Study of Democracy. [online] Available at: <https://escholarship.org/uc/item/2wb616g6> (Accessed 15 September 2020).

Fragile States Index, 2014. Tableau Public. [online] Available at: https://public.tableau.com/profile/davidnicole\#!/vizhome/FragileStatesIndex2014/Fragile States

Ilko Kucheriv «Democratic Initiatives» foundation, 2019. Hromadianske suspilstvo v Ukraini: pohliad hromadian. Opytuvannia [Civil society in Ukraine: the view of citizens. Opinion polls]. [online] Available at: <https://dif.org.ua/article/gromadyanske-suspilstvo-v-ukrainipoglyad-gromadyan> (Accessed 15 September 2020). (In Ukrainian).

Korniievskyi, O.A., Tyshchenko, Yu.A. and Yablonskyi, V.M., 2018. Hromadianske suspilstvo Ukrainy: suchasni praktyky ta vyklyky rozvytku. Analitychna dopovid [Civil Society of Ukraine: Modern Practices and Challenges of Development. Analytical report]. Kyiv: NISD. (In Ukrainian).

Marshall, M.G. and Elzinga-Marshall, G.C., 2017. Global Report 2017: Conflict, Governance and State Fragility. Center for Systemic Peace. [online] Available at: <http://www.systemicpeace.org/vlibrary/GlobalReport2017.pdf> (Accessed 15 September 2020).

Matsiyevsky, Yu.V., 2018. V lovushke gibridnosti: politicheskiy rezhim v Ukraine posle revolyutsii 2014 goda [Trapped in Hybridity: Ukraine's Regime Transformations after the 2014 Revolution]. Polis. Political Studies, 1, pp.96-115. DOI: 10.17976/jpps/2018.01.07 (In Russian).

Minakov, M., 2018. Demodernization in Post-Soviet Eastern Europe. In: Y. Rabkin, M. Minakov, eds., 2018. Demodernization: A Future in the Past. Stuttgart: ibidem-Verlag, pp. 241-260.

Pashyna, N.P., 2013. Formuvannia politychnoi identychnosti v umovakh demokratychnoi transformatsii ukrainskoho suspilstva [Formation of political identity in the conditions of democratic transformation of Ukrainian society]. Luhansk: Noulidzh. (In Ukrainian).

Razumkov Centre, 2007. Kontseptsiia formuvannia zahalnonatsionalnoi identychnosti hromadian Ukrainy [The concept of forming the national identity of the citizens of Ukraine]. National Security and Defence Journal, 9, pp.28-31. (In Ukrainian). 
ISSN 2518-1521 (Online), ISSN 2226-2830 (Print)

ВІСНИК МАРІУПОЛЬСЬКОГО ДЕРЖАВНОГО УНІВЕРСИТЕТУ

СЕРІЯ: ІСТОРІЯ. ПОЛІТОЛОГІЯ, 2020, ВИП. 28-29

Razumkov Centre, 2017a. Identychnist hromadian Ukrainy: tsinnisnooriientatsiinyi aspekt [Identity of Ukrainian Citizens: Value Orientations]. National Security and Defence Journal, 1-2, pp.3-61. (In Ukrainian).

Razumkov Centre, 2017b. Kontseptsiia formuvannia zahalnonatsionalnoi identychnosti hromadian Ukrainy (Proekt) [The Conceptual Approach to the Formation of a Common National Identity of Ukrainian Citizens]. National Security and Defence Journal, 1-2, pp.89-94. (In Ukrainian).

Razumkov Centre, 2017c. Protses formuvannia spilnoi zahalnonatsionalnoi identychnosti hromadian: chynnyky vplyvu, osnovni zasady i napriamy [National Identity Formation: Influential Factors, Basic Principles and Areas of Focus]. National Security and Defence Journal, 1-2, pp.77-88. (In Ukrainian).

Rozumnyi, M.M., red., 2011. Ukraina: politychni stratehii modernizatsii [Ukraine: political strategies of modernization]. Kyiv: NISD. (In Ukrainian).

Schmitter, Ph., 1996. Razmyshleniya o grazhdanskom obshchestve i konsolidatsii demokratii [Some Propositions about Civil Society and the Consolidation of Democracy]. Polis. Political Studies, 5, pp.16-27. (In Russian).

Sørensen, G., 2010. Democracy and Democratization. In: K.T. Leicht, J.C. Jenkins, eds., 2010. Handbook of Politics: State and Society in Global Perspective. New York: Springer, pp.441-458.

The Economist Intelligence Unit's Democracy Index, 2020. The Economist, [online] 22 January. Available at: <https://www.economist.com/graphic-detail/2020/01/22/global-democracyhas-another-bad-year> (Accessed 15 September 2020).

Welzel, C. and Inglehart, R.F., 2015. Politicheskaya kultura, massovye ubezhdeniya i izmenenie tsennostey [Political Culture, Mass Beliefs and Value Change]. Translated from English I.M. Lokshin. In: C.W. Haerpfer, P. Bernhagen, R.F. Inglehart and C. Welzel, eds., 2015. Democratization. Moscow: GU VShE, pp.233-261. (In Russian).

Yesmukhanova, Y., 2018. Nations in Transit 2018. Ukraine. Freedom House. Available at: <https://freedomhouse.org/country/ukraine/nations-transit/2018> (Accessed 15 September 2020).

Zaslavskyi, O., Skrypets, V. and Sokolova, M., 2019. Monitorynhove doslidzhennia Natsionalna stratehiia spryiannia rozvytku hromadianskoho suspilstva v Ukraini. 2016-2020 [A monitoring study of the National Strategy for Civil Society Development in Ukraine (20162020)]. Agency for Legislative Initiatives. [online] Available at: <https://parlament.org.ua/wp-content/uploads/2019/12/Brochure_10.12.19_final.pdf> (Accessed 15 September 2020). (In Ukrainian).

Стаття надійшла до редакції 10.10.2020 p.

\section{O. Mendrin}

FORMATION OF MACROPOLITICAL IDENTITY AS A FACTOR OF SUSTAINABILITY OF DEMOCRATIC DEVELOPMENT IN UKRAINE

The democratic choice of Ukraine was enshrined in most documents that determined the strategic directions of development of the state and society from the moment of gaining independence of the state. Nevertheless, the real progress of Ukraine on the way remains the subject of discussion. The real state of development of the institutions of a democratic society makes it doubtful that the country has passed the stage of consolidation in its democratic transit. The observed trends allow many international organizations to characterize the current state of 
ISSN 2518-1521 (Online), ISSN 2226-2830 (Print) ВІСНИК МАРІУПОЛЬСЬКОГО ДЕРЖАВНОГО УНІВЕРСИТЕТУ СЕРІЯ: ІСТОРІЯ. ПОЛІТОЛОГІЯ, 2020, ВИП. 28-29

development of the country's political system as hybrid. At the same time, experts observe the demodernization of the country and the ongoing degradation of the main political, civilian institutions.

The article analyzes the features of the hybrid regime in Ukraine. An attempt is being made to determine how the real state of development of democracy corresponds to the state of public sentiment, expectations and political values. Using the provisions of the congruence theory, the author makes assumptions about the political consequences of the ongoing disagreement between the interests of society and political elites.

The author concludes that the current state of development requires focused efforts of the state and political elites aimed at stimulating political convictions, emancipatory values that will dominate the mass consciousness, contributing to the progress of political modernization and overcoming the "rollbacks" in democratization. The implementation of a policy of macro-political identity, in which emancipation values will be reflected, can help to overcome demodernization tendencies and further advance Ukraine on the path of democratic transit.

Keywords: macropolitical identity, stability of democracy, civil society, transit.

УДК 94:316.422(55) «1963/1979»

\section{Н. О. Пророченко}

\section{ІРАН: ВІД «БІЛОЇ РЕВОЛЮЦЇ̈» ДО ІСЛАМСЬКОЇ АНТИШАХСЬКОЇ РЕВОЛЮЦЇ. (аналіз суспільно-політичних трансформацій)}

У статті досліджується іранський досвід модернізащіі західного зразка, яка здійснювалася за ініціативою Мохаммеда Рези-шаха Пехлеві у період 1960-1970-х років. Розкрито основні позитивні досягнення реформ та природа породжених ними суспільнополітичних суперечностей. Показано ставлення до реформ представників різних сочіальних груп. Виокремлено основні, на думку автора, причини провалу цьього модернізаційного проекту.

Ключові слова: Іран, модернізація, «біла револючія», шах Мохаммед Реза Пехлеві, іслам, традииійне суспільство.

DOI 10.34079/2226-2830-2020-10-28-29-251-260

У теперішній час багато країн зазнають суттєвих суспільних потрясінь, які пов'язані 3 необхідністю трансформації економічних моделей, зі зміною соціальних запитів населення, зі стрімким розвитком технологій. Дослідники все частіше звертають увагу на складнощі формування комплексної і адекватної відповіді на виклик часу в рамках існуючої ринковоліберальної моделі.

У цьому контексті представляється доцільним звернути увагу на історичний досвід Ірану другої половини XX ст., коли у країні здійснювався пошук прийнятної моделі модернізації суспільства i держави. У процесі історичного розвитку ця держава реалізовувала проекти модернізації різного спрямування - вестернізованого та ісламського. В результаті цих пошуків на теперішній час в країні створена унікальна суспільно-політична 